\title{
ERT monitoring of two Managed Aquifer Recharge ponds in the alluvial aquifer of the Llobregat River (Barcelona, Spain)
}

Sendrós, Alex ; Himi, Mahjoub; Lovera, Raúl; Rivero, Luis; Garcia-Artigas, Ruben; Urruela, Aritz; Casas, Albert

\section{Corresponding Author:}

Alex Sendrós

Universitat de Barcelona Ringgold standard institution - Mineralogy, Petrology and Applied Geology

Barcelona, Barcelona

Spain

alex.sendros@ub.edu

Data Availability: Not Applicable

\begin{abstract}
:
Over the past twenty years, there has been growing interest in the use of the subsurface for water storage using shallow ponds, where water is infiltrated to the subsurface and later groundwater is recovered from pumping wells. This scheme is designed as surface Managed Aquifer Recharge (MAR). Llobregat artificial recharge ponds are MAR systems located in alluvial aquifers near Barcelona with strong significance for water supply to the city. The recharge ponds showed low infiltration rates since the beginning (Ca n'Albareda) and a significant decrease after some months (Sant Vicenç). Consequently, different methodologies were designed for monitoring the systems and evaluating the effectiveness of the selected areas and maintenance procedures. For this purpose, we combined the use of Electrical Resistivity Tomography (ERT) with standard hydrogeological methodologies, including water table monitoring from piezometers and infiltration tests. The combination of direct and indirect methods have allowed us to improve the diagnosis of the subsurface involved in the managed recharge system. The ERT technique has shown to be a costeffective and high-resolution tool, flexible and well adaptable for surveying at different scales without disturbing the recharge process. As a consequence, we demonstrate the usefulness of ERT imaging to unveil hydrogeological heterogeneities and monitoring infiltration, clogging effect and clean-up processes in surface MAR projects.
\end{abstract}

Keywords: ERT, hydrogeophysics, groundwater

This article has been accepted for publication and undergone full peer review but has not been through the copyediting, typesetting, pagination and proofreading process, which may lead to differences between this version and the Version of Record. Please cite this article as doi: 10.1002/nsg. 12113 .

This article is protected by copyright. All rights reserved. 


\section{Introduction}

The River Llobregat aquifers have been a strategic resource for Barcelona city and its Metropolitan Area for more than a hundred years, and have been of fundamental importance to its demographic, industrial and economic development. Groundwater extraction began around 1890 and had, by the $1970 \mathrm{~s}$, reached a sustainable value of about $40 \mathrm{hm}^{3} /$ year, with some years reaching a peak of $120 \mathrm{hm}^{3}$. In recent years, surface water from the River Llobregat and the reservoirs of the River Ter (Sau-Susqueda) has been deployed to preserve the aquifers, and groundwater resources have been strategically preserved to help meet demand during periods of water shortage or episodes of poor-quality river water.

In addition to the historical quantitative problems, over-exploitation of the resource has often compromised groundwater quality through episodes of point-source and diffuse contamination that have affected some wells of the alluvial aquifer of the River Llobregat. Qualitative problems include the long-term impact of salinity caused by urban and industrial discharges, the flow of surface waters through the Catalonian potassic basin and marine intrusion, and contamination from metals and organic compounds of industrial origin and from old uncontrolled landfills that have not been properly sealed (Custodio, 2012). On the other hand, much of the agricultural land has been abandoned and subsequently transformed into industrial areas, suburbs and shopping malls. The changes in land use have produced additional quantitative and qualitative damage, as they have had a significant impact on the natural cycle, reducing the capacity of rainwater to infiltrate due to waterproofing of the soil. Consequently, runoff increases, displacing the water resources downstream and bypassing the natural wastewater treatment offered by the non-saturated zone.

Managed aquifer recharge (MAR) is the intentional recharging of water to suitable aquifers for subsequent recovery or to achieve environmental benefits; the managed process ensures adequate protection of human health and the environment (Bouwer, 2002). The recharge can 
be performed using water from watercourses, storm water and treated wastewater.

The application of this methodology using both surplus water and regenerated water can be a good alternative in densely populated areas with high water demand, where the extractions of this resource largely exceed the natural inflow to the aquifer (de Vries and Simmers, 2002).

The vadose or non-saturated zone (NSZ) has strong implications for the management of water resources and the recharge of aquifers. Potential contaminants released from the surface pass through the NSZ and, before reaching the aquifer, can be altered, partially retained or completely neutralized by physical, chemical and biological processes. However, in practice, the hydrology of the vadose zone is poorly known, mainly because of technical limitations in sampling and the difficulty of reaching further than two metres below ground (Binley, Cassiani and Deiana, 2010). The NSZ, located more than two metres deep, cannot be easily mapped from the surface, but this can be efficiently achieved with the use of surface and single-borehole, borehole-to-borehole and borehole-to-surface geophysical measurements (Hubbard et al., 1997; Slater et al., 1997; Binley et al., 2001, 2002; Alumbaugh et al., 2002; French et al., 2002; Binley and Beven, 2003; Cassiani et al., 2004, 2008, 2009; Cassiani and Binley, 2005; Chang et al., 2006; Deiana et al., 2007; Deiana et al., 2008; Koestel et al., 2008; Looms et al., 2008a, b; Schindler et al., 2010; Gasperikova et al., 2012; Clément et al., 2014, among others).

At this point, it is important to note that direct methods, although usually offering better resolution, require more infrastructure (boreholes and / or piezometers with adequate construction characteristics) and their results are not directly applicable to the hydrogeological characterization of large areas. Reliance on geophysical responses to changes in soil moisture content, gauged through changes in electrical resistivity or dielectric constant, is the key factor that enables non-invasive techniques to be used to monitor the vadose zone in time-lapse mode (repeated measurements over time). The widespread use of 
multi-electrode systems for electrical resistivity tomography (ERT) was a step forward in monitoring, for example, the infiltration of rain into the soil (Benderitter and Schott, 1999), because the use of this technique in different configurations and at different depths of the NSZ can be done at a lower cost (Mitchell, 2010) and can provide high resolution images of hydrogeological structures (Perdomo et al., 2018; Ikard and Pease, 2019; Devi et al., 2020).

The specific objective of this research is to develop a flexible, non-invasive methodology to improve and facilitate the management of surface-type artificial recharge infrastructures (artificial recharge ponds). The methodology has been articulated in different phases, combining data from direct exploration techniques with the use of ERT methodology, adapted to a local work scale and therefore with the corresponding accuracy for each purpose.

\section{Materials and methods}

\section{Study area}

Two different MAR systems have been evaluated using a time-lapse ERT method. Both are located in the northeast of the Iberian Peninsula within the Metropolitan Area of Barcelona city on the floodplain of the River Llobregat (Figure 1).

The area is characterized by a Mediterranean climate with a warm thermal regime in summer and moderate cold in winter. The annual rainfall is moderate, with an average of between 600 and $650 \mathrm{~mm} /$ year. Maximum rain values are recorded in autumn and the driest month is July, coinciding with the highest potential evapotranspiration values (SMC, 2014a, b).

The Ca n'Albareda MAR system is located in the hydrogeological unit of the Cubeta de Sant Andreu de la Barca, while the Sant Vicenç dels Horts. MAR system is located in the hydrogeological unit of the lower Llobregat basin (vall baixa del Llobregat). Both lie over the Quaternary alluvial sediments (ICGC, 2006) of the River Llobregat (Figure 1). 


\section{Artificial recharge ponds of Ca n'Albareda and Sant Vicenç dels Horts}

Recharging aquifers through infiltration ponds is a surface MAR method that involves the construction of one or more excavated ponds that store water to allow it to infiltrate slowly.

The artificial recharge ponds of Ca n'Albareda and Sant Vicenç dels Horts have a similar design and management system. The ponds were artificially excavated in a priori geologically favourable areas without earlier extraction of aggregates. Both are oriented parallel to the river, beyond the riverbed but within its floodplain. The flood return periods are 10 years for the Ca n'Albareda MAR system and 50 years for the Sant Vicenç dels Horts MAR system (ACA, 2015). Once excavated, they form a new wetland area composed of two ponds, each with a differentiated function. The first is the decanting pond, located upstream, where the suspended matter from the water is retained prior to passage to the second, or infiltration pond, where the water recharge process takes place.

The main purpose of the decanting pond is to prevent the formation of silt layers at the bottom of the infiltration pond, which could reduce the mid-term effectiveness of the recharge pond.

The specific features of the Ca n'Albareda ponds are a total length of $220 \mathrm{~m}$, a surface area of $20,000 \mathrm{~m}^{2}$, an average depth of $4 \mathrm{~m}$ and a longitudinal orientation east-west. The design target was for infiltration volumes of the order of $1.7 \mathrm{Hm}^{3} /$ year.

The ponds of the Sant Vicenç dels Horts MAR system are located $11 \mathrm{~km}$ downstream, have a settling surface of about $4,000 \mathrm{~m}^{2}$ and recharge surface of $5,600 \mathrm{~m}^{2}$, a depth of between 4 and 6 metres and their largest dimension is NW-SE. The expected infiltration volumes were 0.4 $\mathrm{Hm}^{3} /$ year. As with those of Ca n'Albareda, they were built between the right bank of the River Llobregat and a large infrastructure (high-speed train line), the water is collected in the River Llobregat about $3 \mathrm{~km}$ upstream of the system and circulates with the force of gravity. Moreover, the Sant Vicenç dels Horts MAR is also equipped to recharge regenerated water 
from the wastewater treatment plant (WWTP) of El Prat de Llobregat. The WWTP is located $12 \mathrm{~km}$ downstream and its effluent, if used for recharging, should be transported through a pumping system.

\section{Electrical resistivity tomography: Acquisition and processing}

ERT data from resistivity and time-lapse imaging was acquired with the IRIS Syscal Pro instrument. The system features an internal switching board for 48 electrodes and an internal $250 \mathrm{~W}$ power source. The system is designed to make resistivity measurements at selected injection electrodes and potential measuring electrodes predefined by the user. Input specifications include electrode array type, combinations of electrode spacing, injection current strength, and the number of measurements to be stacked.

When data acquisition begins, the instrument checks the electrodes for contact and then takes measurements according to the user input acquisition sequence, in our case WennerSchumberger array. Wenner-Schulmberger array was chosen because is moderately sensistive to both horizontal and vertical structures and has a relatively good signal strength (Pazdirek and Blaha, 1996). Typically, ERT data quality is improved by stacking several measurements for each quadripole-transmitter-receiver pair. A data repeatability threshold (3\% standard deviation) has been used to remove noisy measurements from the data. The electrical potentials, input current, and electrode geometry are then used to compute apparent resistivities for input to an inversion algorithm. Prior, filtering on apparent resistivity data was needed to identify and eliminate the noisy data according research objectives and geology setting. In our case, filtering of negative resistivity values and values superior to $1000 \cdot \Omega \cdot \mathrm{m}$ (no bedrock to characterize) was carried out. The software used for ERT inversions was RES2DINV and RES3DINV (Geotomo Software). The subsurface is divided into cells of fixed dimensions and the inversion procedure is based on the smoothness- 
constrained least-squares method. The resistivities are adjusted iteratively until a satisfactory agreement between the input data and the model responses is achieved, based on a nonlinear optimization technique by least-squares fitting (Loke and Barker 1996). During the inversion process, the root-mean-square value of the difference between experimental data and the updated model response is used as a criterion to assess the convergence. The robust leastsquares method was selected because it assumes that the subsurface consists of a few homogeneous regions with a sharp interface between them. Such an inversion scheme is the logical choice where the subsurface comprises units with sharp boundaries in order to determine both layer boundary locations and layer resistivities accurately (Ellis and Oldenburg, 1994). Indeed, it produces models by minimizing the absolute value of data misfit, making it more efficient in removing noise compared to the other inversion methods. In all models, the same damping factor was used, with the initial and minimum values set to 0.15 and 0.03 , respectively. After five iterations, the models reached the desired convergence limits lower than $2.0 \%$, which are acceptable value range of data misfit.

Time-lapse cross-sections have been obtained by plotting the percentage change in the subsurface resistivity of the inversion models for the data sets taken at different times, when compared with the initial data sets (Baker and Moore, 1998). The inversion of the data sets was carried out using a joint inversion technique where the model obtained from the initial data set was used to constrain the inversion of the later time data sets (Loke, 1999).

\section{Infiltration process monitoring}

The discharge of water into the infiltration pond and to the NSZ below it changes the electrical resistivity values of the subsurface (Baker and Moore, 1998). The ERT technique has been chosen to study the changes in the resistivity values in the subsoil, due to the artificial recharge process and the consequent evolution of the moisture front over time. Other geophysical methods such as Ground Penetrating Radar (GPR) using $50 \mathrm{MHz}$ antennas and 
Induction Electromagnetic (IEM) using EM-31 equipment have been applied without significant results. The presence of clays in the NSZ could be a limiting factor in the case of the GPR and IEM results were rejected due to low resolution.

For monitoring purposes, the acquisition of the same ERT profile was repeated at regular time-lapse intervals during water infiltration into the recharge pond. The monitoring of the infiltration process and the evolution of the moisture front was carried on the ponds of $\mathrm{Ca}$ n'Albareda (November 2011) and those of Sant Vicenç dels Horts (May 2011 and February 2012) with a different working scale (ERT line length) and different periodicity between consecutive time-lapse acquisitions in each of the two sites (Table 1).

\section{Clogging process and maintenance actions monitoring}

One of the main concerns faced by the managers of artificial recharge ponds is the process of soil clogging in the infiltration ponds (Hanson et al., 2014; Jasper, 2014). Clogging is the process by which the infiltration pond gradually loses its initial hydraulic characteristics (decrease in porosity and hydraulic conductivity), both in its horizontal and vertical components. When clogging is very severe, the ground surface does not allow water to infiltrate, so the system is no longer effective. Although a pond is designed to operate for about 25 years, poor system design or inappropriate operation can reduce its service life to a few years (Pedescoll, 2010).

Clogging can be due to the sedimentation of suspended particles in the infiltration water (physical) and / or biofilm occurrence (Seifert and Engesgaard, 2012), vegetal debris deposition, root and rhizome growth (biological) and chemical precipitation of compounds (García et al., 2007).

In the case of the Ca n'Albareda infiltration ponds, a few months after reopening in 2010, the infiltration ponds operated at significantly lower infiltration rates than the design parameters $\left(1-2 \mathrm{~m}^{3} / \mathrm{m}^{2}\right.$ day). A pilot excavation was placed in a pond sector and two infiltration tests 
were carried out with the double ring or Muntz infiltrometer. The Muntz infiltrometer measures the rate at which water moves into soil. This rate becomes constant when the saturated infiltration rate for the particular soil has been reached (Gregory et al., 2005).

The purpose of the pilot excavation was to remove the upper layer, formed of gravels in a silty-clay matrix, in the most favourable zone for artificial recharge. To eliminate this, it was necessary to make an excavation 0.8 metres deep. Subsequently, Muntz infiltration tests were performed in an area outside (It1) and inside (It2) the excavation area, to make a comparison of the values of infiltration rates obtained (Table 2).

On the Sant Vicenç dels Horts site, in order to monitor clogging processes and the effect of maintenance tasks on an infiltration pond, five parallel ERT cross-sections, each 94 metres long, were acquired on the ground surface of the infiltration pond. These five acquisitions were repeated in four campaigns in April 2011, January 2012, February 2013 and September 2013 in the same position (using a double-frequency GPS), with the same number of electrodes (48) and distance between the electrodes (2 metres) and using the same array (Wenner-Schlumberger).

The first campaign was performed after placing a reactive layer on the ground surface, the second after 134 days of artificial recharge, the third after 384 days of infiltration and the fourth just after performing one of the maintenance tasks (Table 2). At the same time, infiltrated volume data were recorded continuously with a flowmeter located in the pipe that connects the decanting and the infiltration ponds, in order to obtain the infiltration rates.

\section{Results and discussion}

\section{Infiltration process monitoring}

For the monitoring of infiltration through the NSZ, acquisition of the same ERT profile was repeated at regular time intervals (time-lapse) while water was infiltrating the recharge ponds. On Ca n'Albareda site, we obtained 21 ERT cross-sections in total. The progressive water This article is protected by copyright. All rights reserved. 
inflows on infiltrating surfaces produce a difference in resistivity values from the first crosssection (CAI1), acquired in dry conditions (baseline), to the last cross-section (CAI21), acquired in a completely saturated area. Time-lapse comparisons from last to baseline acquisition show a reduction of $20 \%$ in resistivity values $(1.39 \mathrm{~m}$ to $2.75 \mathrm{~m}$ deep) and, therefore, the advance of the moisture front in the subsurface of the recharge pond (Figure 2). The test was concluded after five hours. There were no significant differences below 3.25 metres, due to the influence of the water table in homogenizing the resistivity values obtained.

In the case of the Sant Vicenç dels Horts recharging pond, the evolution of the infiltration process was monitored in two campaigns, with a decreasing number of acquisitions.

The first campaign (2011) was the most detailed and can be divided into three stages:

- Before discharging water into the infiltration pond. We carried out three ERT acquisitions and made a results comparison.

- During water infiltration. Two consecutive acquisitions were made at the beginning of the process, and five when the whole ground surface was completely flooded.

- After water ceased recharging the system. We obtained three additional cross-sections.

We compared the results (one for each stage), as an example of the distribution of resistivity values in the ground pond surface, before infiltration (SVI1), after 17 hours of infiltration (SVI7) and nine hours after cessation of infiltration (SVI8). In all three acquisitions, after the inversion process, two common geoelectric units could be identified:

- The first and most superficial (0 to 5 metres deep), is defined by an increase of resistivity values (up to $800 \Omega \cdot \mathrm{m}$ ) in the vertical direction from surface to bottom. It is interpreted as unconsolidated granular type sediments with a variable moisture content.

- The second comprises the lower part of the cross-section, including the basal section (from 5 metres deep to the lower limit of the cross-section), and is defined by a decreasing sequence 
of resistivity values (up to values of less than $30 \Omega \cdot \mathrm{m}$ ) in a top to bottom direction. It is also interpreted as the resistivity response produced by granular type sediments, in this case saturated.

Comparing the absolute values of the inverted resistivities in the three cross-sections (Figure 3), a decrease in the resistivity values is observed after 17 hours of recharge process and identified in the first 5 metres of depth (section SVI7 vs section SVI1). Nine hours after the end of the infiltration process, the resistivity values are increased. However, they do not reach the baseline resistivity values (section SVI8 vs section SVI1).

The second campaign (2012) was carried out by comparing an acquisition taken before the infiltration with another from the day after the beginning of the infiltration, always from the same position as in the previous campaign. In this case, the number of acquisitions is lower due to knowledge acquired in the first campaign about the response of the medium, and the results are described in a more synthetic way, directly from the percentage variation data of inverted resistivity values.

The results of the percentage variation in the geoelectric cross-sections allow for discrimination between two zones: one in the upper levels, with variations of more than $50 \%$ (between 0 and 5 metres deep) and another (located at the bottom), with variations of below $50 \%$ with a predominance of variation values lower than $10 \%$ (Figure 4 ).

On both monitored sites, the infiltration process caused a progressive decrease in the resistivity values obtained, according to the NSZ response, until they were more than $50 \%$ lower than the values found before starting the recharge procedure. The decrease is of a different magnitude, depending on the area of the analysed cross-section, which can be explained by the heterogeneity of the subsoil of the ponds in both case studies. The heterogeneity makes it difficult to use methodologies for estimating punctual NSZ hydrogeological parameters from vertical electrical conductivity profiles for instance (Mawer 
et al., 2013). However, the main process occurring at larger scale are highlighted with ERT infiltration monitoring (Travelletti et al., 2011) and it could be an outstanding tool in smallmedium budget MAR projects.

In the specific case of the Sant Vicenç dels Horts ponds, the results of the two infiltration monitoring campaigns using the ERT technique are consistent with each other. The small differences between the results being mainly due to a surface maintenance action that was carried out in the area (scarification of the first $20 \mathrm{~cm}$ ) in order to recover initial infiltration rates.

\section{Clogging process and maintenance actions monitoring}

Regarding the results of the monitoring of the clogging effect in the Ca n'Albareda recharge pond, infiltration tests showed different durations and water quantities to achieve the water saturation rate (Table 2) and different infiltration rates. Infiltration rates of $0.54 \mathrm{~m}^{3} / \mathrm{m}^{2}$ per day on the original surface of the pond and $3.98 \mathrm{~m}^{3} / \mathrm{m}^{2}$ per day at 0.8 metres deep. The infiltration rates in double-ring infiltrometer assays are approximately equivalent to the vertical hydraulic conductivity of the vadose zone for a geological setting (Bouwer, 1962).

For the location of the pilot excavation on the Ca n'Albareda pond, and once the clogging problems were evident, the geophysical information acquired in an earlier ERT campaign was critical (Sendrós, 2016). The geophysical data provided the only available information with a representative lateral distribution of the heterogeneity of the pond subsoil. The pond area with the highest resistivity values in its NSZ was chosen to construct the pilot zone. Lower resistivity values are related to low hydraulic conductivity layers (Ayers, 1989) and we decided to avoid this to minimize excavation works. When results of the two infiltration tests carried out are compared with geophysical output data, a higher infiltration rate value is identified in the areas with higher resistivities and a lower infiltration rate in areas with lower 
resistivities values. This relationship is maintained whether the inversion of resistivity is performed using 2D or 3D algorithms (Figure 5).

At the Sant Vicenç dels Horts site, the cross-sections obtained from the first ERT campaign have a maximum depth of 13 metres and the geoelectrical response of the upper formation of alluvial origin and the position of the water table. In this type of sedimentary environment, electrical resistivity values are usually lower, the lower the grain size, and they are also low when the sediments are saturated.

The results of the second (January 2012) and third (February 2013) acquisition campaigns have been used to compare the values of electrical resistivity when the pond was operating at the designed infiltration rate, with the resistivity values when the infiltration rate decreased and there was evidence of clogging on the surface (Figure 6).

Figure 7 shows the result of the SVC1 cross-sections from the two different campaigns, and a decrease of the resistivity values, in the upper levels of the section, is identified when comparing February 2013 with the January 2012 results. The decrease is apparent from the presence of values of 90 to $250 \Omega \cdot \mathrm{m}$ (at 0.5-1.5 metres deep) and by the predominance of 390 to $600 \Omega \cdot \mathrm{m}$ values at $1.5-6$ metres deep (instead of more than $600 \Omega \cdot \mathrm{m}$ ).

When the percentage change in the inverted resistivity values between the two cross-sections is represented (lower part of Figure 7), a decrease in resistivity values in the subsoil of the pond is also identified. The decrease is quantified in values of -50\% (0-6 metres deep) with variable thickness from 3 metres in the central area of the cross-section to 6 metres in the southern and northern sectors.

On the other hand, the results of the fourth ERT monitoring campaign, on the Sant Vicenç dels Horts recharge pond (September 2013), have been used to identify the effects of maintenance tasks on the resistivity values of the pond subsoil. The maintenance was carried out just before the fourth campaign acquisition and consisted of the scarification (ploughing) 
of the pond surface to restore the original infiltration rates. The process was carried out with light machinery to avoid compacting the soil, which would have caused an additional decrease in the infiltration capacity of the system.

The results are represented as percentage variations of inverted resistivity values for crosssections SVC1, SVC2, SVC3, SVC4 and SVC5, acquired in the third campaign, those acquired in the fourth ERT campaign (Figure 8) and values of inverted resistivity and crosssection SVC1, acquired in the second and fourth ERT campaigns (Figure 9).

In Figure 8, an increase in resistivity values of up to $60 \%$ in the most superficial part of the recharge area is identified. The area affected by the increase has a variable thickness within each of the cross-sections (between 1 and 6 metres deep). It can also be observed that there is a variable width of the section according to the ERT cross-section interpreted. For example, the thickness and continuity of increase is higher in SVC5 than in SVC4; geoelectrical crosssections separated from each other by only 10 metres.

Figure 9 shows the change in electrical resistivity values of the SVC1 cross-section, acquired when the infiltration rate was optimal (January 2012) and after the maintenance performed to recover optimal rates (September 2013). The image shows a reduction of resistivity values (more than $30 \%$ ) in practically the entire prospected subsurface.

The results of the fourth ERT campaign (September 2013) confirm that although the maintenance managed to reduce the electrical resistivity values of the NSZ of the pond over the water table (0-6 metres deep), the initial reference values (January 2012) were not achieved, neither were the initial recharge rates matched after the clean-up procedure. 


\section{Conclusions}

- The development of efficient strategies for the management of groundwater resources requires accurate characterization of the hydrogeological structure and subsequent lateral heterogeneities of the geological environment.

- The ERT is a non-destructive, cost-effective and high-resolution technique that enables straightforward continual measurement of electrical resistivity distribution at the subsurface. It is a flexible and adaptable methodology to work with different scales and arrays since it can be left permanently installed to carry out periodical acquisitions without disturbing the recharge process in the infiltration pond.

- The distribution of resistivity values has been represented in both two-dimensional crosssections and three-dimensional models. The interpretation of those representations has allowed estimations of the variation of hydrogeological and hydrogeophysical properties both in depth and laterally. For the purposes of water management, to conduct the infiltration process, it is particularly important to characterize and avoid low resistivity zones due to fine grain size sediments and low permeability areas' response.

- The use of complementary direct and indirect techniques such as infiltration tests and the ERT method allowed us to improve the analysis of the non-saturated zone for better characterization of the geological environment involved in the managed recharge system.

- Finally, it is advisable to apply the methodology described here repeatedly over time, in order to characterize the possible development of clogging in the infiltration pond and to control the correct operation of the recharge system. This would guarantee optimal operational effectiveness and, therefore, an improved cost-effectiveness ratio for the whole process. 


\section{Acknowledgements}

This research was funded by the Spanish Ministry of Economy, Industry and Competitiveness MINECO through the Challenges for de Society Program RETOS CGL2013-48802. Thanks, are also due to Victoria Colomer from Catalan Water Agency (ACA) and Enric Queralt from Community of Water Users of Llobregat Delta Water's (CUADLL) for their continuous assistance and for provide the access to the experimental sites.

Finally, the authors thank Ismael Casado, Helena Ortiz, Helena Gallardo, Gal·la Serra and Juan Moral for their considerable contribution with the collection of field data.

\section{References}

ACA 2015. Planning the alluvial spaces of the Baix Llobregat and Anoia basins (in catalan). Departament de Territori i Sostenibilitat, Generalitat de Catalunya.

Alumbaugh, D., Chang, P.Y., Paprocki, L., Brainard, J.R., Glass, R.J. and Rautman, C. 2002.

Estimating moisture contents in the vadose zone using cross-borehole ground penetrating radar: A study of accuracy and repeatability. Water Resources Research 38, 45-1-45-12.

Ayers, J.F. 1989. Conjunctive Use of Geophysical and Geological Data in the Study of an Alluvial Aquifer. Groundwater 27, 625-632.

Baker, R. and Moore, J. 1998. The application of time-lapse electrical tomography in groundwater studies. The Leading Edge 17, 1454-1458.

Benderitter, Y. and Schott, J.J. 1999. Short time variation of the resistivity in an unsaturated soil: the relationship with rainfall. European Journal of Environmental and Engineering Geophysics 4, 37-49.

Binley, A. and Beven, K., 2003. Vadose Zone Flow Model Uncertainty as Conditioned on Geophysical Data. Ground Water 41, 119-127. 
Binley, A., Cassiani, G. and Deiana, R. 2010. Hydrogeophysics: opportunities and challenges. Bollettino di Geofisica Teorica ed Applicata 51, 267-284.

Binley, A., Cassiani, G., Middleton, R. and Winship, P. 2002. Vadose zone flow model parameterisation using cross-borehole radar and resistivity imaging. Journal of Hydrology $267,147-159$.

Binley, A., Winship, P., Middleton, R., Pokar, M. and West, J. 2001. High-resolution characterization of vadose zone dynamics using cross-borehole radar. Water Resources Research 37, 2639-2652.

Bouwer, H. 1962. Field Determination of Hydraulic Conductivity Above a Water Table with the Double-Tube Method. Soil Science Society of America Journal 26, 330-335.

Bouwer, H. 2002. Artificial recharge of groundwater: hydrogeology and engineering. Hydrogeology Journal 10, 121-142.

Cassiani, G. and Binley, A. 2005. Modelling unsaturated flow in a layered formation under quasi-steady state conditions using geophysical data constraints. Advances in Water Resources 28, 467-477.

Cassiani, G., Fusi, N., Susanni, D. and Deiana, R. 2008. Vertical radar profiling for the assessment of landfill capping effectiveness. Near Surface Geophysics 6, 133-142.

Cassiani, G., Giustiniani, M., Ferraris, S., Deiana, R. and Strobbia, C. 2009. Time-lapse surface-to-surface GPR measurements to monitor a controlled infiltration experiment. Bollettino di Geofisica Teorica ed Applicata 50, 209-226.

Cassiani, G., Strobbia, C. and Gallotti, L. 2004. Vertical Radar Profiles for the Characterization of Deep Vadose Zones. Vadose Zone Journal 3, 1093-1105.

Chang, P.-Y., Alumbaugh, D., Brainard, J. and Hall, L. 2006. Cross-borehole groundpenetrating radar for monitoring and imaging solute transport within the vadose zone. Water Resources Research 42.

This article is protected by copyright. All rights reserved. 
Clément, R., Moreau, S., Henine, H., Guérin, A., Chaumont and C., Tournebize, J. 2014. On the value of combining surface and cross-borehole ERT measurements to study artificial tile drainage processes. Near Surface Geophysics 12, 763-775.

Custodio, E. 2012. Low Llobregat Aquifers: Intensive Development, Salinization, Contamination, and Management. In The Llobregat. The Story of a Polluted Mediterranean River (Sabater, S., Ginebreda, A. and Barceló, D. editors) pp. 27-49, Springer. de Vries, J. and Simmers, I. 2002. Groundwater recharge: an overview of processes and challenges. Hydrogeology Journal 10, 5-17.

Deiana, R., Cassiani, G., Kemna, A., Villa, A., Bruno, V. and Bagliani, A. 2007. An experiment of non-invasive characterization of the vadose zone via water injection and crosshole time-lapse geophysical monitoring. Near Surface Geophysics 5, 183-194.

Deiana, R., Cassiani, G., Villa, A., Bagliani, A. and Bruno, V. 2008. Calibration of a Vadose Zone Model Using Water Injection Monitored by GPR and Electrical Resistance Tomography. Vadose Zone Journal 7, 215-226.

Devi, A., Israil, M., Singh, A., Gupta, P.K., Yogeshwar, P. and Tezkan, B. 2020. Imaging of groundwater contamination using 3D joint inversion of electrical resistivity tomography and radio magnetotelluric data: A case study from Northern India. Near Surface Geophysics.

Ellis, R.G. and Oldenburg, D.W. 1994. Applied geophysical inversion: Geophysical Journal International, 116, 5-11.

French, H.K., Hardbattle, C., Binley, A., Winship, P. and Jakobsen, L. 2002. Monitoring snowmelt induced unsaturated flow and transport using electrical resistivity tomography. Journal of Hydrology 267, 273-284.

García, J., Rousseau, D., Caselles-Osorio, A., Story, A., De Pauw, N. and Vanrolleghem, P. 2007. Impact of Prior Physico-Chemical Treatment on the Clogging Process of Subsurface 
Flow Constructed Wetlands: Model-Based Evaluation. Water, Air, and Soil Pollution 185, $101-109$.

Gasperikova, E., Hubbard, S.S., Watson, D.B., Baker, G.S., Peterson, J.E., Kowalsky, M.B., Smith, M. and Brooks, S. 2012. Long-term electrical resistivity monitoring of rechargeinduced contaminant plume behaviour. Journal of contaminant hydrology 142-143, 33-49.

Gregory, J.H., Dukes, M.D., Miller, G.L. and Jones, P.H. 2005. Analysis of Double- Ring Infiltration Techniques and Development of a Simple Automatic Water Delivery System. Applied Turfgrass Science 2, 1-7.

Hanson, R.T., Lockwood, B. and Schmid, W. 2014. Analysis of projected water availability with current basin management plan, Pajaro Valley, California. Journal of Hydrology 519, $131-147$.

Hubbard, S.S., Peterson, J.E., Majer, E.L., Zawislanski, P.T., Williams, K.H., Roberts, J. and Wobber, F. 1997. Estimation of permeable pathways and water content using tomographic radar data. The Leading Edge 16, 1623-1628.

ICGC 2003. Mapa Geològic de Catalunya 1:250 000. Departament de Territori i Sostenibilitat, Generalitat de Catalunya.

ICGC 2006. Mapa hidrogeològic del tram baix del Llobregat i el seu delta 1:3 000 . Departament de Territori i Sostenibilitat, Generalitat de Catalunya.

Ikard, S. and Pease, E. 2019. Preferential groundwater seepage in karst terrane inferred from geoelectric measurements. Near Surface Geophysics 17, 43-53.

Jasper, C.A. 2014. Combined geophysical methods for mapping infiltration pathways at the Aurora Water Aquifer recharge and recovery site. Ph Thesis. Colorado School of Mines.

Koestel, J., Kemna, A., Javaux, M., Binley, A. and Vereecken, H. 2008. Quantitative imaging of solute transport in an unsaturated and undisturbed soil monolith with 3-D ERT and TDR. Water Resources Research 44. 
Loke, M.H. and Barker, R.D. 1996. Rapid least-squares inversion of apparent resistivity pseudosections by a quasi-Newton method. Geophysical Prospecting 131-152.

Loke, M.H 1999. Time-lapse resistivity imaging inversion. Proceedings of the $5^{\text {th }}$ Meeting of the Environmental and Engineering Geophysical Society European Section.

Looms, M.C., Binley, A., Jensen, K.H., Nielsen, L. and Hansen, T.M. 2008a. Identifying Unsaturated Hydraulic Parameters Using an Integrated Data Fusion Approach on CrossBorehole Geophysical Data. Vadose Zone Journal 7, 238-248.

Looms, M.C., Jensen, K.H., Binley, A. and Nielsen, L. 2008b. Monitoring Unsaturated Flow and Transport Using Cross-Borehole Geophysical Methods. Vadose Zone Journal 7, 227237.

Mawer, C., Kitanis, P., Pidlisecky, A. and Knight, R. 2013. Electrical Resistivity for Characterization and Infiltration Monitoring beneath a Managed Aquifer Recharge Pond. Vadose Zone Journal 12 (1).

Mitchell, V.R. 2010. Informed Electrical Resistivity Imaging for monitoring infiltration dynamics in the near surface. Ph Thesis. Stanford University.

Pazdirek, O. and Blaha, V. 1996. Examples of resistivity imaging using ME-100 resistivity field acquisition system. En European Association of Geoscientists \& Engineers, ed. EAGE 58th Conference and Technical Exhibition Extended Abstracts. Amsterdam.

Pedescoll, A. 2010. Clogging in horizontal subsurface flow constructed wetlands. Measures, design factors and prevention strategies. Ph Thesis. Universitat Politècnica de Catalunya.

Perdomo, S., Kruse, E.E. and Ainchil, J.E. 2018. Estimation of hydraulic parameters using electrical resistivity tomography (ERT) and empirical laws in a semi-confined aquifer. Near Surface Geophysics 16, 627-641. 
Schindler, U., Durner, W., von Unold, G., Mueller, L. and Wieland, R. 2010. The evaporation method: Extending the measurement range of soil hydraulic properties using the air-entry pressure of the ceramic cup. Journal of Plant Nutrition and Soil Science 173, 563-572.

Seifert, D. and Engesgaard, P., 2012. Sand box experiments with bioclogging of porous media: hydraulic conductivity reductions. Journal of contaminant hydrology 136-137, 1-9.

Sendrós, A., Himi, M., Lovera, R., Casado, I. and Casas, A. 2013. Estimating recharge potential and preferential flow paths in a meander close to a recharge pond using ERT, Near Surface Geoscience 2013, 370-374.

Sendrós, A. 2016. Using geophysical techniques in planning and management of groundwater resources. Application to Mediterranean aquifers. Ph Thesis. Universitat de Barcelona.

Slater, L.D., Zaidman, M.D., Binley, A. and West, L.J. 1997. Electrical Imaging of Saline Tracer Migration for the Investigation of Unsaturated Zone Transport Mechanisms. Hydrology and Earth System Sciences 1, 291-302.

SMC, 2014a. Climatology. El Baix Llobregat (in catalan). Departament de Medi Ambient i Habitatge, Generalitat de Catalunya.

SMC, 2014b. Climatology. El Vallès Occidental (in catalan). Departament de Territori i Sostenibilitat, Generalitat de Catalunya.

Travelleti, J., Sailhac, P., Malet, J.P., Granjean, G. and Ponton, J. 2011. Hydrological response of weathered clay-shale slopes: water infiltration monitoring with time-lapse electrical resistivity tomography. Hydrological processes 26, 2106-2019. 


\section{List of Legends}

Figure 1 Upper. Location sketch of studied areas. Lower. Hydrogeological setting. A: Ca

(1) n'Albareda recharge ponds, B: Sant Vicenç dels Horts site. Modified from ICGC (2003).

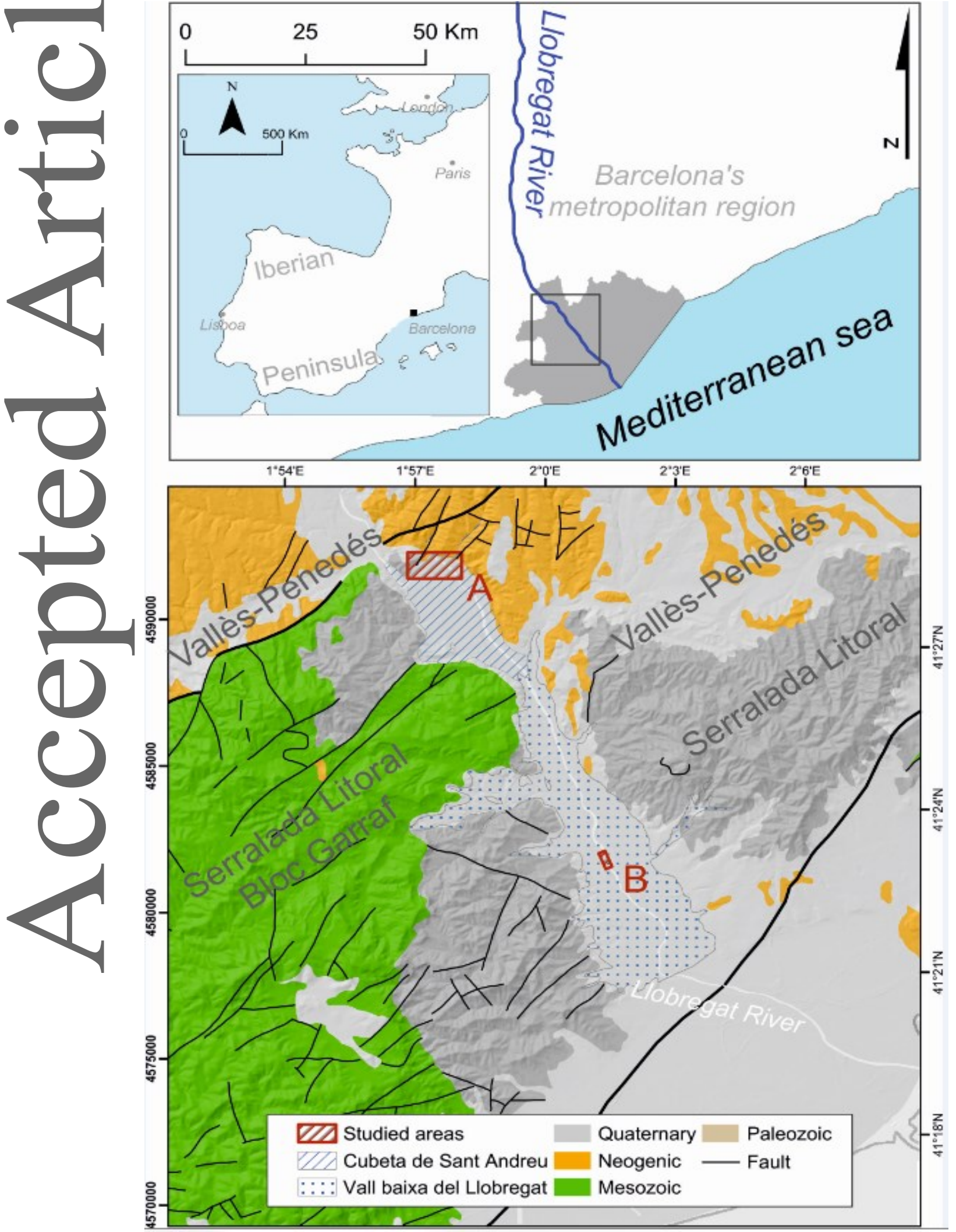

This article is protected by copyright. All rights reserved. 
Figure 3 Baseline geoelectrical cross-section SVI1 (upper). Percentage change in model resistivity between ERT timesteps SVI7 and SVI1 (center) and between SVI8 and SVI1

(lower).

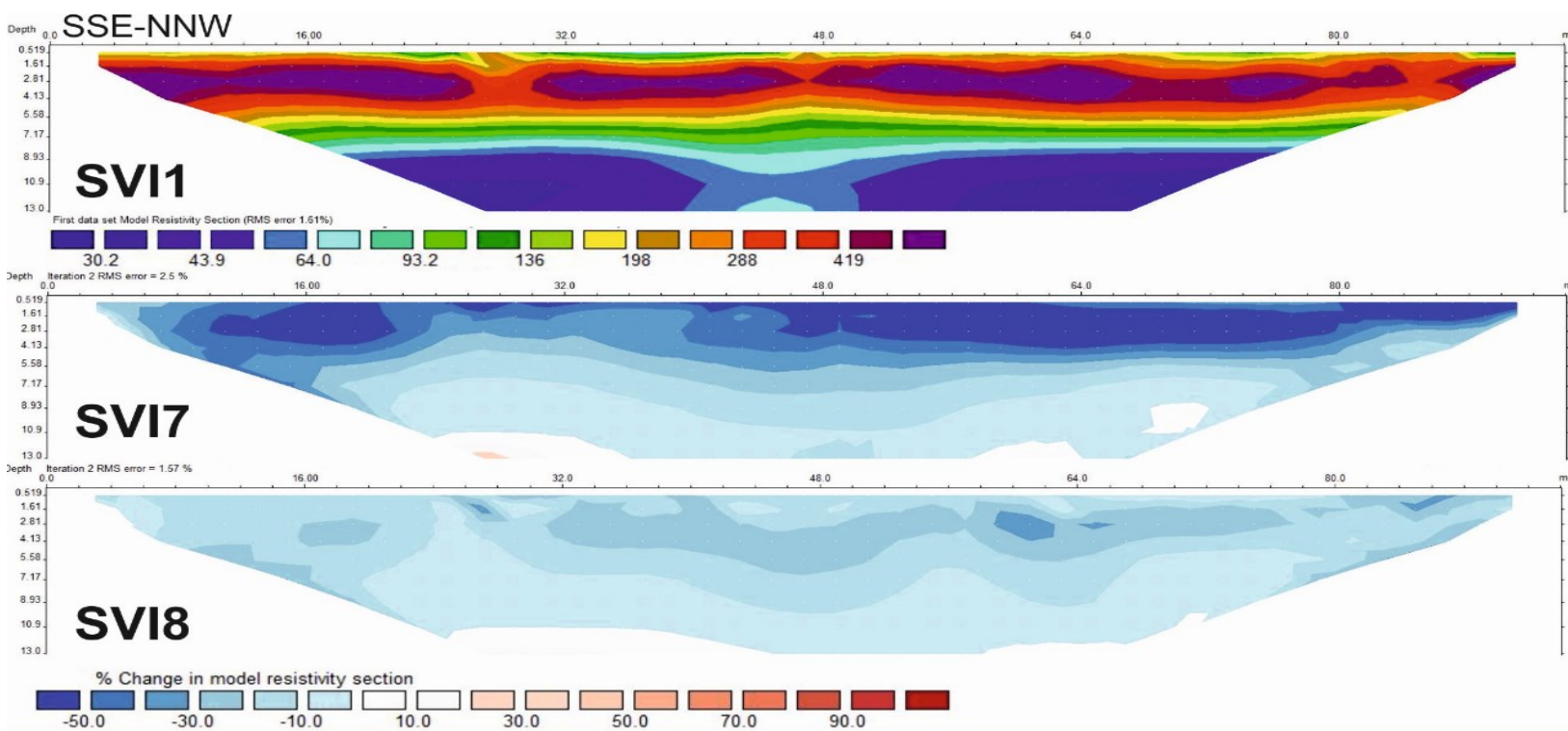

Figure 4 Geoelectric cross-section acquired before the entry of water into the pond (upper), the same acquired with the flooded pond (central) and the percentage changes on resistivity values between the dry and the flooded acquisitions (lower).

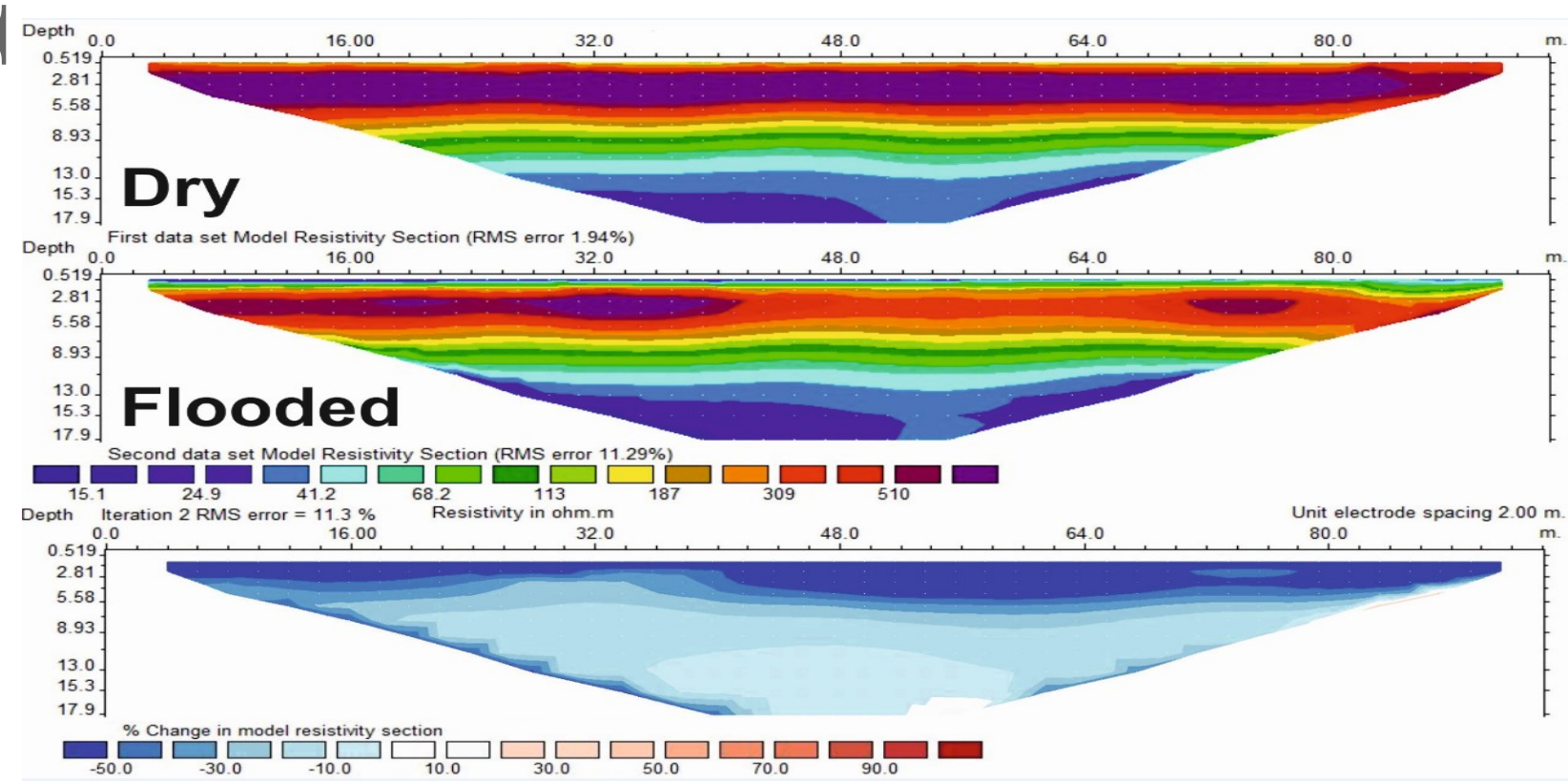

This article is protected by copyright. All rights reserved. 
Figure 7 Geoelectric cross-section SVC1 acquired in January 2012 (upper part), acquired in February 2013 (middle part) and percentage variation of inverted resistivity values between

(1) them (lower part).
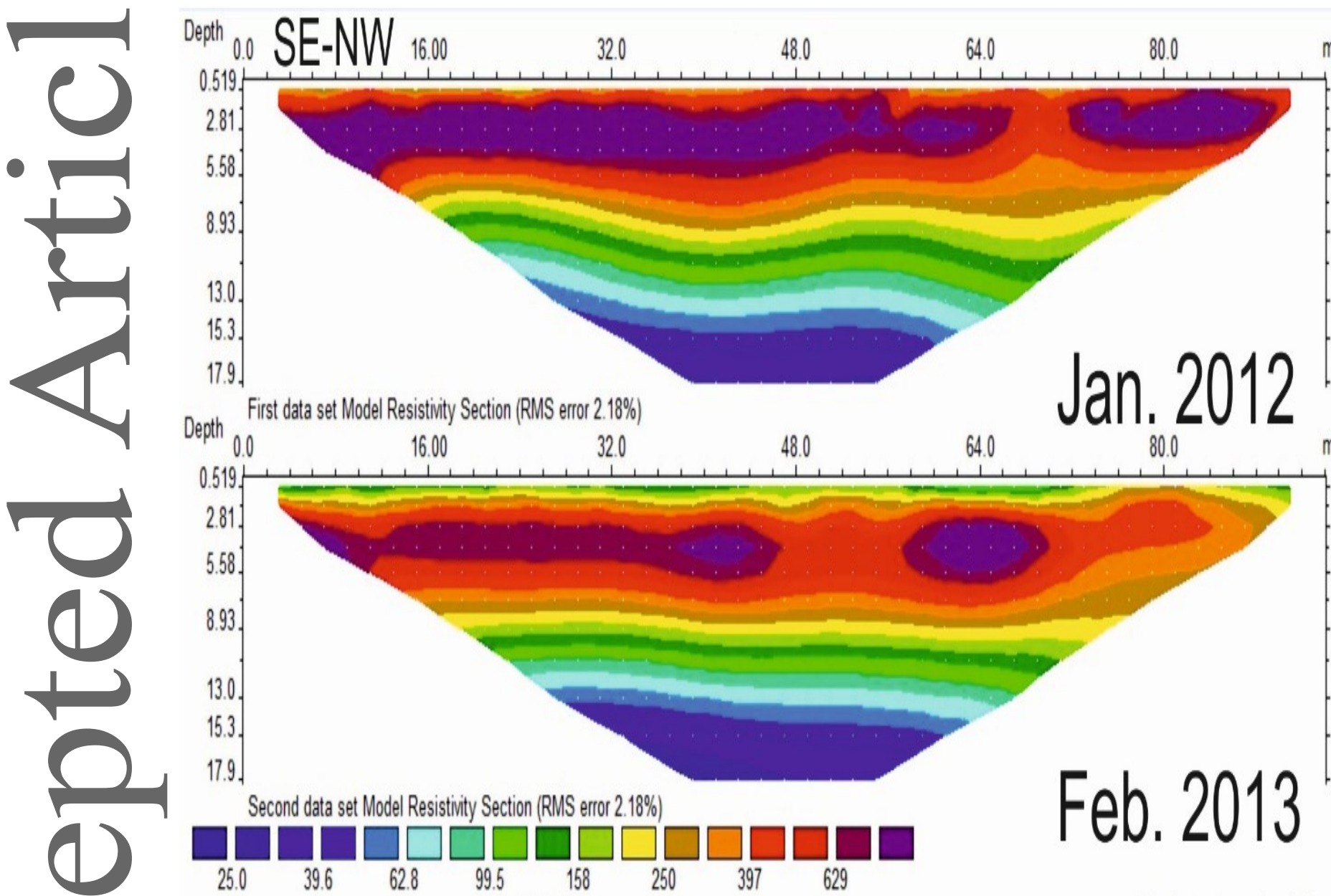

Depth Iteration 5 RMS error $=2.2 \% \quad$ Resistuity in ohm.m
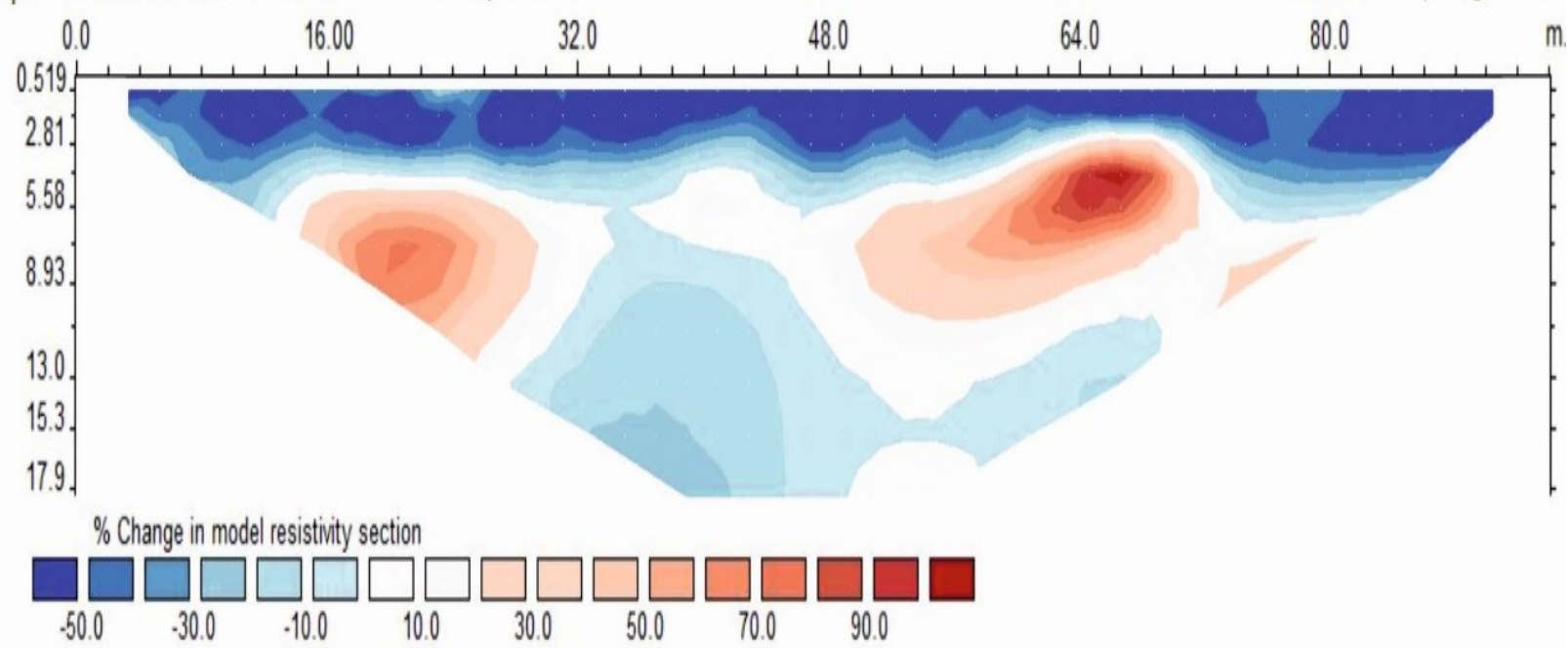
Figure 9 ERT time-lapse on Sant Vicenç dels Horts recharge pond. Resistivity values before (upper) and after (middle) carry out a maintenance procedure to remove clogging effect.

Lower part shows the percentage change in model resistivity.

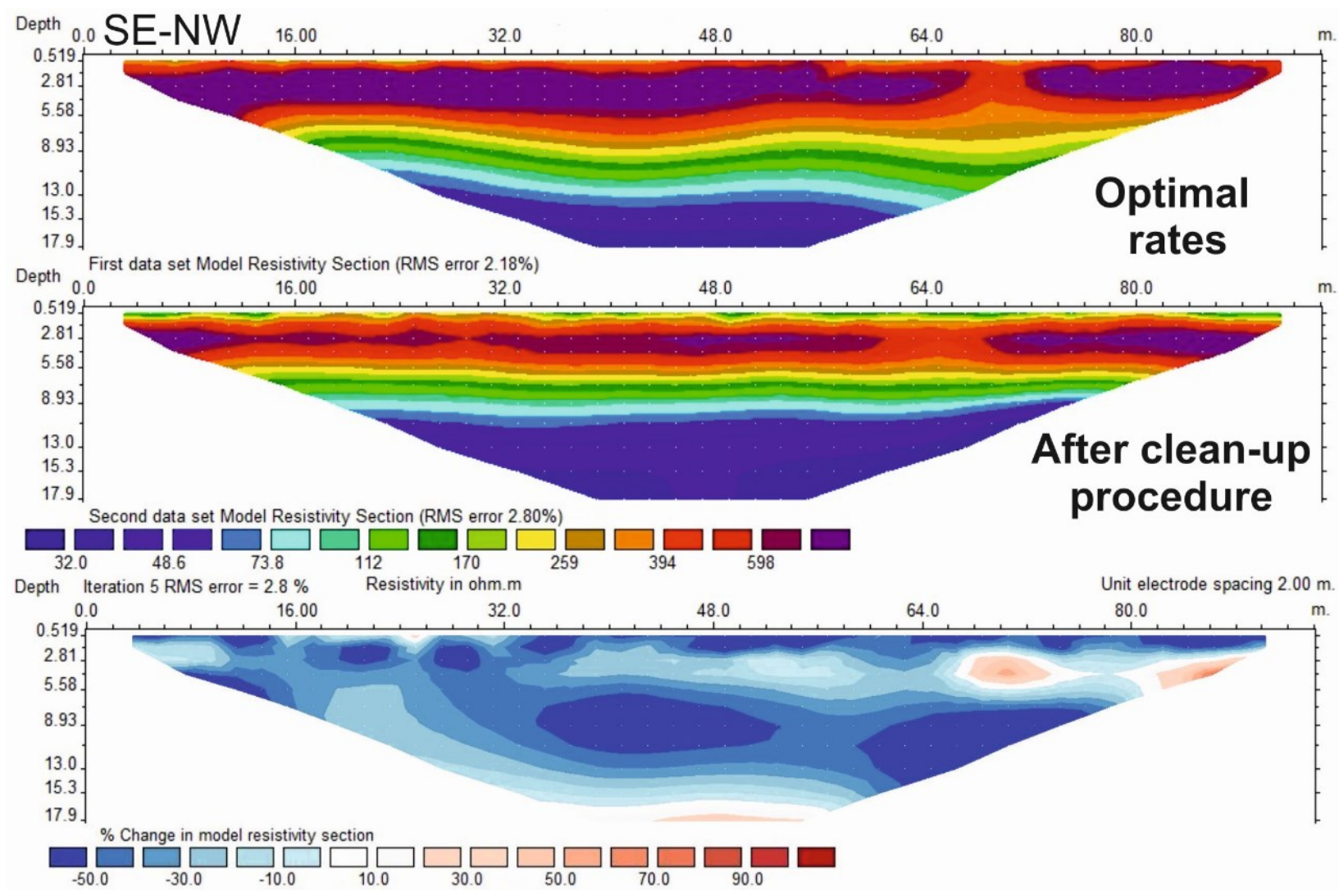

Table 1 ERT campaigns for infiltration process monitoring

\begin{tabular}{ccccc}
\hline $\begin{array}{c}\text { Cross-section } \\
\text { ID }\end{array}$ & Acquisition date & Site & $\begin{array}{c}\text { Water Table } \\
\text { depth }(\mathrm{m})\end{array}$ & Field notes \\
\hline CAI1 & November 2011 & Ca n'Albareda & 3.06 & Before infiltration \\
\hline CAI21 & November 2011 & Ca n'Albareda & 2.99 & 5 hours infiltration \\
\hline SVI1 & May 2011 & Sant Vicenç & 5.15 & Before infiltration \\
\hline SVI7 & May 2011 & Sant Vicenç & No data & $\begin{array}{c}17 \text { hours } \\
\text { infiltration }\end{array}$ \\
\hline SVI8 & May 2011 & Sant Vicenç & No data & $\begin{array}{c}\text { 9 hours after } \\
\text { ceased infiltration }\end{array}$ \\
\hline Dry & February 2012 & Sant Vicenç & 5.40 & Before infiltration \\
\hline Flooded & February 2012 & Sant Vicenç & No data & 18 hours
\end{tabular}

This article is protected by copyright. All rights reserved. 
infiltration

Table 2 ERT campaigns and infiltration tests conducted for clogging process and maintenance actions monitoring.

\begin{tabular}{|c|c|c|c|c|}
\hline ID & Type & Acquisition date & Place & Field notes \\
\hline $\begin{array}{l}\text { CAC5 and } \\
\text { CAC19 }\end{array}$ & $\begin{array}{l}\text { ERT cross- } \\
\text { sections }\end{array}$ & February 2011 & Ca n'Albareda & $\begin{array}{l}\text { Infiltration procedure } \\
\text { below designed rates }\end{array}$ \\
\hline It1 & $\begin{array}{l}\text { Infiltration } \\
\text { test }\end{array}$ & June 2011 & Ca n'Albareda & $\begin{array}{l}\text { Original pond surface. } \\
\text { Water used }=100 \mathrm{I} . \\
\text { Duration }=3 \text { hours }\end{array}$ \\
\hline It2 & $\begin{array}{l}\text { Infiltration } \\
\text { test }\end{array}$ & June 2011 & Ca n'Albareda & $\begin{array}{c}0.8 \text { metres deep. } \\
\text { Water used }>300 \mathrm{I} . \\
\text { Duration }>10 \text { hours }\end{array}$ \\
\hline SVC1 to SVC5 & $\begin{array}{l}\text { ERT cross- } \\
\text { sections }\end{array}$ & April 2011 & Sant Vicenç & $\begin{array}{l}\text { Infiltration pond } \\
\text { commissioning }\end{array}$ \\
\hline SVC1 to SVC5 & $\begin{array}{l}\text { ERT cross- } \\
\text { sections }\end{array}$ & January 2012 & Sant Vicenç & $\begin{array}{l}\text { After } 134 \text { days of } \\
\text { infiltration procedure }\end{array}$ \\
\hline SVC1 to SVC5 & $\begin{array}{l}\text { ERT cross- } \\
\text { sections }\end{array}$ & February 2013 & Sant Vicenç & Clogging evidences \\
\hline SVC1 to SVC5 & $\begin{array}{l}\text { ERT cross- } \\
\text { sections }\end{array}$ & September 2013 & Sant Vicenç & $\begin{array}{l}\text { After clean-up } \\
\text { procedure }\end{array}$ \\
\hline
\end{tabular}

This article is protected by copyright. All rights reserved. 